Revista Iberoamericana, Vol. LXVIII, Núm. 199, Abril-Junio 2002, 331-354

\title{
POPULISMO E HIBRIDACIÓN: DIOS SE LO PAGUE, TEXTOS Y CONTEXTO
}

POR

Paulo Antonio Paranaguá*

El sistema de los estudios y el florecimiento del cine de géneros favoreció en América Latina el desarrollo de auténticas estrategias internacionales, donde hasta entonces habían predominado proyectos individuales e iniciativas aisladas. Dios se lo pague (Luis César Amadori, Argentina, 1948) es un buen ejemplo de la adecuación entre estrategias transnacionales, representaciones elocuentes e hibridación genérica, con una convergencia excepcional entre los tres principales países productores de América Latina: Argentina, México y Brasil (además de aportes españoles). La acertada utilización del star system y de las opciones genéricas contribuyó a la adhesión del público del continente. Sin necesidad de recurrir a particularismos locales, el argumento de tono social entraba en resonancia con el discurso político en boga. Eran tiempos de populismo: Juan D. Perón fue elegido dos veces para la presidencia argentina, en 1946 y 1951; Getulio Vargas volvió al poder en las elecciones brasileñas de 1950, después de haberlo ocupado de 1930 a 1945. El auge de los estudios de Buenos Aires y México, la “época de oro” de la que hablan historiadores y nostálgicos del cine clásico, corresponde al apogeo del nacionalismo, a una auténtica época de oro del populismo latinoamericano.

Deus lhe pague, la pieza original de Joracy Camargo, estrenada en São Paulo en 1932, fue el mayor éxito de Procópio Ferreira (Río de Janeiro, 1898-1979), el “príncipe del teatro brasileño”, el astro del primer repertorio desprendido del género chico, anterior al advenimiento de la psicología y al teatro moderno. Procópio la representó más de tres mil veces, ${ }^{1}$ encarnando el triunfo de la inteligencia y la sabiduría sobre la juventud. Publicada en Brasil, tuvo veinte y pico ediciones, un fenómeno inédito. ${ }^{2}$ La principal metamorfosis

\footnotetext{
${ }^{*}$ Este texto es parte de un libro en fase de elaboración sobre Tradición y modernidad en el cine de América Latina.

${ }^{1}$ Tres mil doscientas veintiséis veces, según el mismo Procópio Ferreira en una entrevista de 1974 (Depoimentos 99), tres mil seiscientas veintiuna representaciones en Brasil y en el extranjero, según Jalusa Barcellos (24). El primero recuerda cuatrocientas y veintiseis piezas representadas (99); la segunda le atribuye cuatrocientas sesenta y una, en sesenta y seis años de carrera (20), amén de una grabación de Deus lhe pague para la televisión (37).

${ }^{2}$ Véase Camargo, Deus lhe pague (la paginación utilizada para nuestras citas se refiere a esta octava edición). La primera edición apuntada por la Bibliografia da dramaturgia brasileira (São Paulo, ECA-USP/Museu Lasar Segall, 1981, 52-53) corresponde a la editorial Alba (Río de Janeiro, 1933); también figura la traducción al castellano, Dios se lo pague (Buenos Aires: Argentores, 1935) y una
} 
operada por Dios se lo pague al pasar de las tablas a la pantalla fue el cambio radical de género, de la comedia al melodrama. De cierta manera, las demás modificaciones argumentales o de puesta en escena son una consecuencia de esa transformación dramatúrgica. Aunque el flash-back sobre el pleito entre el obrero y el patrón ya estuviera en la pieza, el interés de la obra radicaba en dos duelos, uno verbal y el otro dramático. El diálogo entre el falso Mendigo (el "Mendigo de medianoche”, según el título francés del film, le Mendiant de minuit) y el Otro permitía exponer El Capital para pobres de espíritu. La competencia entre el Millonario maduro y el joven Péricles por el corazón de Nancy confirmaba la superioridad de la razón sobre los arrebatos sentimentales.

Para los que no tuvimos la suerte o la oportunidad de conocer a Procópio Ferreira en el escenario, queda el consuelo de intentar imaginarlo a través del pálido reflejo que nos han legado una docena de películas, ninguna de ellas muy trascendente. La comedia $O$ homem dos papagaios (Armando Couto, Multifilmes, Brasil, 1953) tiene por lo menos la ventaja de acercarnos a su transformismo, esencial para interpretar con éxito el doble papel de pordiosero y ricachón de Deus lhe pague. Aunque el hábito no hace al monje, sí ayuda mucho al actor. Procópio era un hombre de corta estatura pero robusto, con una nariz imponente y rasgos que le conferían una máscara natural. La locución impostada denotaba la herencia lusitana del espectáculo brasileño, que sería superada en sucesivas etapas por la chanchada [la comedia bufa] carioca, el teatro de Nelson Rodrigues, el documental con sonido directo y las telenovelas. A pesar de ello, Procópio encarnaba al principio de $O$ homem dos papagaios a una especie de malandro de buen corazón, un fracasado de edad madura con familia a cuestas. El arquetipo de malandro ya le había sido atribuido en una chanchada, Berlim na batucada (Luiz de Barros, Cinédia, 1944), después del papel dramático de Pureza (Chianca de Garcia, Cinédia, 1940, basada en José Lins do Rêgo). Pero la comedia paulista tiene ingredientes distintos a la carioca, sin recurrir de manera tan sistemática a la carnavalización. En O homem dos papagaios, Procópio abandona enseguida el uniforme de vendedor de helados para endosar la informalidad del vago doméstico. Convocado por un compañero de juventud enriquecido, procede a vestir el traje de domingo detrás de un biombo, como si repitiera frente a la cámara el clásico recurso teatral. La vestimenta le cae tan bien que engaña casi sin quererlo al nuevo vecindario, dispuesto a tomarlo por un excéntrico millonario. ${ }^{3}$ No obstante, el malandrín se hace transparente en su comportamiento de nuevo rico. Ambos coexisten en la expresión y en la gesticulación del actor, que escribió el argumento y sus propios diálogos para mayor lucimiento de sus dotes expresivas. Sin embargo, el desenlace ya muestra a un auténtico caballero, transformado por la experiencia. Aunque la película sea bastante elemental en su desarrollo, permite adivinar los recursos de un hombre que crecía en el

traducción francesa, Dieu vous le rende : le mendiant de minuit (Río de Janeiro: Imprensa Nacional, 1959). Deus lhe pague es el tercer título de la colección portuguesa "Livros do Brasil," junto a obras de Erico Veríssimo (el novelista de mayor éxito antes de Jorge Amado), Gilberto Freyre, José Lins do Rêgo y Machado de Assis, que le confieren un precoz estatuto de "clásico" [Véase Joracy Camargo, Deus lhe pague (Lisboa: Edição Livros do Brasil, s.d., cuarta edición. Prefacio de Procópio Ferreira)]. Una traducción alemana de 1948 tuvo como título Bettlerkomödie.

3 “Excentricidad de millonario" admitida por el mismo Procópio en su comportamiento personal, en los mencionados Depoimentos 100. 
escenario hasta adquirir la altura de un mito viviente, capaz de seducir a varias generaciones del respetable público, incluso más allá de las fronteras de Brasil.

Los tres actos de la pieza del brasileño Joracy Camargo tienen una estructura idéntica: dos pordioseros conversan en la puerta de la iglesia (el Mendigo y el Otro). Una parte del relato del protagonista introduce el cambio de escena y decorado, gracias a la iluminación. Esos raccontos funcionan como flash-backs, perfectamente encuadrados por la conversación e identificados con el punto de vista del Mendigo. Por lo tanto, la filosofía destilada en los diálogos tiene un carácter preponderante a lo largo de la obra. En el primer acto, el flashback sobre la estafa sufrida por el protagonista cuando trabajaba en una fábrica ilustra sus palabras y explica sus motivaciones. La mujer, Nancy, y el pretendiente Péricles da Silva, aparecen embutidos en el segundo acto. En esa ocasión, el Mendigo le toma el pelo al rival, en torno a los orígenes griegos de su nombre. El racconto contenido en el tercer acto presenta el proyecto de fuga de los dos jóvenes, la humillación de Péricles por el viejo, la revelación de su doble identidad frente a Nancy, seguida por el desafío de que se vaya con el rival. El desenlace ocurre enseguida en el mismo acto.

Al final del primer acto, después de haber contado sus desgracias, el Mendigo resume sus convicciones: "La vida es una sucesión de acontecimientos inevitables... como la lluvia, el viento, la tempestad... el día y la noche... Todo lo que ocurre es la vida. (...) Vivir es razonar. Y el razonamiento es el supremo bien de la vida. Quien razona no sufre...” (5456). El Mendigo prefiere "vivir al margen”(57), entre otras cosas porque "un hombre inteligente nunca se conformará con un sueldo, por mayor que sea. El empleo, con salario fijo, es el ideal del hombre vencido en la vida” (64). Aparte de la razón y la inteligencia, hay una tercera calidad. Cuando el Otro dice: "A esta hora no pasa nadie aquí... ", el Mendigo contesta: "En cambio pasa la vida...” El Otro replica: "La vida no da limosnas...” y el Mendigo rebate: "Da. Da la gran limosna, que no todos saben recoger: Experiencia” (66).

La disimetría de edad es uno de los fundamentos dramáticos de Deus lhe pague. En palabras del Mendigo: “Ella es joven todavía y yo ya soy viejo. Mi vejez es definitiva. La juventud de ella es provisional. Me detuve en la vejez y estoy esperando que ella envejezca, para que seamos felices" (68). En palabras de Nancy a Péricles: "Sale contigo la juventud y llega dentro de poco, con él... la vejez” (73). La superioridad del primero sobre el segundo radica en la fusión de la experiencia acumulada con los años y un razonamiento inteligente: "La vejez solo debilita a los animales irracionales... porque les falta la inteligencia para substituir a la fuerza bruta” (88). El Mendigo es “un hombre viejo, cuya fuerza moral y cuya inteligencia aún están vigorosas”(88). Y “la mujer, que es invencible, se rinde frente a la inteligencia...” (115). Cuando Nancy atribuye su atracción a la fuerza del destino, el Mendigo corrige: “No es el destino. Es la fuerza de la inteligencia” (137). Cuando decide finalmente rechazarlo, Nancy le lanza a Péricles: “Amor, prestigio, todo lo que me ofreces es efímero. Solo hay una cosa eterna: es la inteligencia. Amor, belleza, fortuna, ¡nada resiste a la fuerza de la inteligencia!” (146).

Todo en un tono de fina ironía, empezando por los dos pordioseros capaces de citar a Upton Sinclair, Anatole France o Karl Marx: "El comunismo es como aquel muñeco de paja que nos asusta cuando somos niños” (98). Aunque el protagonista proponga la formación de un sindicato de mendigos y la corrección de las desigualdades por medio de 
una nueva organización de la sociedad, las frases valen por su irreverencia y efectismo verbal, sin que las propuestas adquieran mayor seriedad. El Mendigo considera ridículos a los pequeño burgueses, que eran entonces los principales espectadores del teatro: "La humanidad se compone de miserables, falsos ricos y ricos falsos. La peor clase es la de los falsos ricos...” (126). “Si yo hablara como los demás, sería banal. Y un viejo banal no interesa ni siquiera a sí mismo”(139).

La comedia de Joracy Camargo fue representada en otros escenarios de América Latina, ${ }^{4}$ adelantándose así a la potencial repercusión de la adaptación fílmica. El cine no inventó la circulación de las obras, sino que le dió una nueva dimensión gracias a los mecanismos de reproducción industrial y difusión comercial. Deus lhe pague tuvo mucho éxito en Buenos Aires, al punto de presentarse en varios teatros al mismo tiempo, ${ }^{5}$ como si correspondiera a una coyuntura de transición entre el cinismo social, herencia del crack de 1929 o de la "década infame” — desconfianza perfectamente formulada por el tango “Cambalache” (1935) de Enrique Santos Discépolo_ - y el voluntarismo populista de la década siguiente, atemperado por las posibilidades del diálogo constructivo entre mendigos y millonarios, obreros y patrones, ricos y pobres, todos hombres de buena voluntad. El autor, influenciado seguramente por el ambiente social que rodeó en Brasil a la llamada Revolución de 1930, respondía a la crisis con "una especie de apólogo filosófico" (Almeida Prado, Procópio Ferreira 46 y ss). Quizás por primera vez en el país, un obrero subía a las tablas. Aunque la gracia estuviera en la invención verbal, Deus lhe pague se acercaba a un teatro de tesis, dentro de los estrechos límites del escenario brasileño de la época, con su leccioncita sobre el origen de la propiedad privada, o sea la apropiación indebida, el robo, un "abc del marxismo, explicado por el Método Berlitz de preguntas y respuestas,” según el crítico Almeida Prado. El izquierdismo del texto estaba convenientemente neutralizado por el conflicto central, la disputa por la mujer.

Joracy Camargo es hoy un autor olvidado, con escasas líneas en las enciclopedias y obras de referencia sobre el teatro. No obstante, en Brasil su obra cumple un papel en la transición entre la vieja y la nueva dramaturgia, representada por un Dias Gomes, el autor de O pagador de promessas (llevada a la pantalla por Anselmo Duarte, Palma de Oro del festival de Cannes en 1962). Dias Gomes, dramaturgo que debutó con Procópio Ferreira (Pé de cabra, 1942), es a su vez un puente entre la escena y el melodrama redivivo de la telenovela (escribió por ejemplo la célebre Roque Santeiro, TV Globo, 1986). Una

\footnotetext{
${ }^{4}$ En toda América Latina, suelen decir las ediciones brasileñas de la pieza, una afirmación imposible de avalar sin la correspondiente comprobación.

${ }^{5}$ Dos teatros, según Domingo Di Nubila (93); cuatro según la nota previa de los editores de la pieza mencionada supra (14). Raymundo Magalhães Júnior recuerda haber visto al gran actor Alfredo Camiña en una de las versiones porteñas, hacia 1934-1935 [Véase la presentación de Deus lhe pague (Río de Janeiro: Ediouro, 1998, col. Prestigio), 5]. César Maranghello identifica un segundo intérprete: Santiago Arrieta (235). El productor Atilio Mentasti atribuye una de las puestas en escena a Mario Soffici (citado en España, Medio siglo 25). Una foto muestra a Procópio Ferreira frente a un cartel que anuncia el estreno ese día de Dios se lo pague interpretado por él mismo en el teatro Colombo de Buenos Aires, en 1948, el año en que se distribuye la película; otra lo muestra siendo homenajeado en la capital argentina junto a personalidades como Luis Sandrini y Paulina Singerman, si bien el pie de foto dice que la temporada prevista no se realizó (Barcellos 230-31).
} 
investigación sobre el repertorio representado por Procópio Ferreira confirma la existencia de un verdadero eje Río de Janeiro-Buenos Aires, los dos principales focos del espectáculo sudamericano en la primera mitad del siglo xx. Un listado de las piezas extranjeras interpretadas por el actor brasileño contiene cincuenta y tres títulos franceses, treinta y dos españoles, veintinueve alemanes, dieciocho argentinos, doce húngaros, diez italianos, seis ingleses, cinco norteamericanos y cuatro portugueses. ${ }^{6}$ Aparte del predominio europeo, la lista revela la inconsistencia de la separación absoluta entre las culturas de la América hispánica y Brasil. En términos intelectuales, la distancia entre Portugal y su antigua colonia es muchísimo mayor que la de España y los países hispanoamericanos, incluso en un terreno durante tanto tiempo dependiente de la vieja metrópoli, como es el teatro. La fuerte presencia de autores españoles seleccionados por Procópio Ferreira, sumada al notable contingente de obras argentinas, muestra la existencia de intensas relaciones que no respetan la divisoria del meridiano de Tordesillas. Buenos Aires era el primer destino de las giras al exterior para los espectáculos musicales brasileños (por ejemplo, Carmen Miranda o Pixinguinha y sus Batutas), y viceversa, como lo comprueba la etimología de la palabra chanchada. La adaptación de Deus lhe pague en estudios porteños se inserta en ese intercambio.

En un libro de memorias, Procópio dedica casi treinta páginas, un capítulo entero, a justificar la puesta en escena de piezas argentinas, criticadas por los nacionalistas en nombre de la defensa de los autores locales (Ferreira, "O teatro argentino" 61-89). Aparte de recordar que él mismo brindó su primera oportunidad a veintisiete dramaturgos brasileños (entre ellos, Oduvaldo Vianna, Raymundo Magalhães Júnior, Pedro Bloch, Guilherme Figueiredo, Alfredo Mesquita, además de los mencionados Joracy Camargo y Dias Gomes), el gran actor entona un verdadero himno al "magnífico intercambio con la Argentina” (85). Las largas citas sacadas de la prensa carioca muestran una auténtica polémica durante los años veinte, cuya intensidad sugiere la importancia creciente del citado eje Río de Janeiro-Buenos Aires. El popular cronista João Ribeiro llega a escribir lo siguiente:

Un destino que se afigura y define lenta pero seguramente es el de la unidad sudamericana. No hablo de la unidad política, sino de la unidad espiritual de la raza ibérica del nuevo mundo. La lengua de los sudamericanos es la misma o casi la misma, idéntica es la religión y las mezclas étnicas son sobremanera parecidas. Y a pesar de ello, los sudamericanos parecen desconocerse... Hasta hace poco tiempo, raramente nos llegaba uno u otro nombre, aparte de la órbita política y del caudillismo... ${ }^{7}$

Si en el ámbito del espectáculo popular el intercambio entre Brasil y Argentina podía despertar polémicas o pasiones, también existía un flujo subterráneo entre las vanguardias de ambos países. Quienes tienen en mente apenas las tenebrosas convergencias de las dictaduras militares (simbolizadas por el Plan Cóndor) o los intereses contradictorios del Mercosur, tal vez no recuerden las oscilaciones pendulares que caracterizan a las

\footnotetext{
${ }^{6}$ Investigación de Sábato Magaldi citada por Almeida Prado (Peças, pessoas, personagens 73).

7 João Ribeiro, "Sul-Americanos,” Revista da Semana (Río de Janeiro, 18 de abril de 1925), reproducido en Ferreira, "O teatro argentino" 75.
} 
relaciones mutuas. En el siglo XIX, Argentina y Brasil unieron sus fuerzas para combatir contra el pobre y progresista Paraguay en la Triple Alianza. Cien años después, la guerra contra el viejo aliado alimentaba las especulaciones estratégicas de sus respectivos estados mayores. Si durante buena parte del siglo xx los intelectuales ignoraron la cultura de sus vecinos, hay más puntos de contacto entre los dos países sudamericanos que entre cualquiera de ellos y México. Emir Rodríguez Monegal ha rastreado el diálogo entre Mário de Andrade y Jorge Luis Borges. ${ }^{8}$ Jorge Schwartz ha hecho una lectura comparada de Oliverio Girondo y Oswald de Andrade. ${ }^{9}$ Cuatro figuras emblemáticas de la modernidad literaria revelan destinos cruzados hasta entonces insospechados. Jorge Schwartz ha señalado asimismo una convergencia insólita entre ambos nacionalismos: el escritor Monteiro Lobato sería el verdadero autor de La Nueva Argentina, la edificante novela didáctica destinada a promover el primer plan quinquenal peronista. ${ }^{10}$ Sin duda, sería posible ampliar los canales subterráneos entre las dos culturas, en ámbitos tan distintos como la fotografía (Horacio Coppola y su trabajo sobre Aleijadinho, Ricardo Aronovich en tránsito entre la generación del sesenta y el Cinema Novo) o el psicoanálisis (Emilio Rodrigué, Juana Elbein dos Santos).

Eso, sin olvidar nuestro tema, el cine, con figuras tan diferentes como el cineasta Carlos Hugo Christensen o los discípulos de la escuela documental de Fernando Birri, instalados en Brasil, y a la inversa, las incursiones del dramaturgo paulista Oduvaldo Vianna por los estudios porteños (director de El hombre que nació dos veces, 1938; argumentista de Amor, Luis Bayón Herrera, 1940). El cómico aragonés Pablo Palitos tuvo una temporada carioca muy recordada por Grande Othelo (93 y ss), antes de viajar a Buenos Aires con la compañía de Jardel Jércolis. El uruguayo Fernando Borel triunfó en los casinos brasileños, antes de emprender giras por países latinoamericanos y radicarse en la Argentina (Blanco Pazos y Clemente 82-83). Y el antecedente inmediato del viaje de Atilio Mentasti por varios países de América Latina habría sido el éxito de un film desaparecido, ¡Eramos seis! (Carlos Borcosque, 1945), basado en una novela de la brasileña María José Dupré. En esa ocasión, el directivo de Argentina Sono Film compró los derechos de la pieza de Joracy Camargo (por algo más de tres mil pesos, según Di Núbila, una módica suma) y contrató a Arturo de Córdova. Para su distribución en Brasil, ¡Eramos seis! habría sido incluso doblado al portugués (España, Medio siglo 213; Di Nubila 94).

\footnotetext{
${ }^{8}$ Resultan muy agudas las comparaciones del autor de Macunaíma entre el modernismo paulista y la vanguardia porteña, amén de sus acotaciones sobre "la confianza del argentino y la inseguridad del brasileño" (Rodríguez Monegal 79).

${ }^{9}$ Véase Schwartz, Vanguarda e cosmopolitismo na década de 20: Oliverio Girondo e Oswald de Andrade. El mismo Jorge Schwartz ha escrito un texto con título de manifiesto: "Down with Tordesillas."

${ }^{10}$ Véase Schwartz, "Down with Tordesillas" 284. Fundamentado en la ficha catalográfica de la biblioteca de la Universidad de São Paulo, que menciona el nombre de Monteiro Lobato entre paréntesis, después del presunto autor Miguel P. García [La Nueva Argentina (Buenos Aires: Editorial Acteon, 1947)]. Puramente anecdótica resulta en cambio la atribución de una madre brasileña a Manuel Penella da Silva, ghost writer de Eva Perón para el best-seller oficial La razón de mi vida (Buenos Aires: Peuser, 1952), por Horacio González [Evita (São Paulo: Brasiliense, 1983): 10].
} 
Volviendo a Deus lhe pague, el crítico e historiador Decio de Almeida Prado opina que la conversación entre el Mendigo y el Otro es la base de sustentación de la obra. Todo lo demás, incluso la disputa por la mujer, no pasa de pretexto para que dos pordioseros sentados a la sombra de una iglesia discurran sobre el sentido de la vida. Ya en plena decadencia, cuando Procópio Ferreira seguía representando su papel de mayor éxito en el interior de Brasil, recurrió a una estratagema: "Procópio mandó hacer, con escasos recursos técnicos, una versión cinematográfica de la mayoría de las escenas, dejando intactas, sin embargo, las conversaciones entre los dos mendigos, interpretadas por él en vivo. Semejante mezcla heterodoxa de cine y teatro le permitía ahorrar fuerzas físicas, aparte de dispensar el cambio de decorados y reducir sustancialmente la nómina de pagos del elenco" (Almeida Prado, Peças, pessoas 48, 66).

Evidentemente, la adaptación de Dios se lo pague filmada en los estudios de Argentina Sono Film respondió a otras consideraciones. La estructura de la película es muy distinta, pero lo importante no son los desplazamientos en el relato, ni la multiplicación de escenarios y personajes en sí mismos, sino los deslizamientos de sentido operados por su inserción en el conjunto. Aunque Dios se lo pague vuelva tres veces al diálogo entre los dos pordioseros, la narración fílmica no resulta de la conversación con el discípulo, ni está siempre identificada con el punto de vista de un único protagonista, muy por encima de todos los demás. Ello debilita el "apólogo filosófico", aun antes de que entremos a analizar otras modificaciones significativas.

El film Dios se lo pague empieza con el encuentro y el primer intercambio de los dos mendigos en el umbral de la iglesia, después de los créditos sobre una oscura calle embarrada. La secuencia siguiente ocurre en el Club de Residentes, justo enfrente, donde funciona un casino clandestino. Allí se conocen Nancy y Richardson, un jugador que ha perdido el crédito en el establecimiento, como lo muestra un áspero diálogo con el gerente. Una redada de la policía facilita el encuentro entre la mujer y el Mendigo, que le propone frecuentar otros ambientes si desea entablar relaciones más estables: la música favorece los sentimientos. En el hotel donde vive, Nancy zafa de la cuenta siguiendo los consejos del "viejito". Al día siguiente, recibe flores y una invitación anónima para un concierto. En el lujoso Auditorium, mientras escuchan "Tannhauser” y "Lohengrin” de Wagner, el hombre despojado del disfraz de pordiosero — el público lo reconoce, ella no- primero la libra del chófer de taxi que intenta cobrarse y luego le hace la corte. La galantería es atribuida en parte a la melodía y se sirve de los motivos de las composiciones ejecutadas por la orquesta. Sin embargo, ella siente un malestar y confiesa que está en ayunas. Van a un restaurante y salón de baile. Cuando ella regresa al hotel no puede eludir el desalojo y vuelve enseguida a los brazos del seductor. Ambos establecen una especie de pacto, consistente en no averiguar el pasado del otro.

Hasta aquí, predominan en Dios se lo pague los recursos de la alta comedia, a ratos algo solemne. Transcurrida media película (la duración total es de ciento diecinueve minutos), hay un progresivo cambio de tono, como si el melo-drama acompañara la ambientación musical. Con excepción del encuentro entre los dos indigentes, el falso y el verdadero, el maestro y el discípulo, todo lo demás ha sido añadido por el guionista de Dios se lo pague, Tulio Demicheli. Incluso la siguiente frase atribuida al Mendigo: "El dinero es triste, tiene como el hombre su pecado original”. No solamente la ecuación pecaminosa 
no consta en la pieza, sino que refleja una "filosofía" bastante alejada de la expuesta en tono risueño por Joracy Camargo. “Todo dinero es vil”, llega a decir Péricles da Silva (145). Pero la religión está presente en el autor brasileño bajo la forma de un claro relativismo:

Todas las religiones son perfectas. Los hombres son los que son imperfectos. Si fundáramos una secta que ofreciera a la hora de la comunión, en lugar de la hostia, un suculento bife con patatas, veríamos como no le faltarían adeptos. (...) Si un día convocaran un congreso de todas las iglesias para discutir los puntos controvertidos, terminarían por negar la existencia de Dios... (127-28)

Volviendo al film Dios se lo pague, los dos pordioseros se dirigen hacia la mansión de Mario Alvarez, nombre del que logró amasar una fortuna a costa de limosnas. Por la calle, constatan la hipocresía de la servidumbre y de los convivas invitados a una fiesta. Cuando Nancy, la dueña de casa, reencuentra a Péricles, su temor es que pueda chantajearla y revelar su vida anterior. Una serie de evocaciones, cortos flashs-backs, desfilan en sobreimpresión sobre su cabeza, mientras ella observa la ventana de espaldas a la cámara. En la pantalla, Péricles Richardson y Mario Alvarez tienen edades y físicos absolutamente equivalentes, otra diferencia fundamental respecto a la pieza, donde Péricles da Silva enfrenta a "un viejo que podría ser mi abuelo" (74). Dicho sea de paso, la principal disparidad en cuanto a los nombres de los personajes no radica en el divertido y significativo cambio de apellido de Péricles, sino en que el Mendigo (Mario Alvarez) y el Otro (Barata) hayan salido del anonimato en que los mantuvo voluntariamente Joracy Camargo.

Luego, los dos pordioseros de Dios se lo pague van al taller donde el primero guarda sus utensilios “profesionales” y asistimos al desmaquillaje del falso Mendigo. Allí, este se refiere a una época en que "todavía no se habían inventado las leyes de protección obrera”, introduciendo el único flash-back de la película — dividido en dos partes sucesivas - sobre la visita del patrón a su casa, el robo de los planos elaborados por el empleado, el suicidio de la esposa engañada, el intento de revancha en la fábrica, seguido de los años de cárcel. El Mendigo ofrece a su aprendiz Barata el taller, con dos puertas que dan hacia calles de aspecto distinto, lo que llama la atención sobre la importancia de los dispositivos escenográficos bipolares.

Richardson promete a Nancy el matrimonio, en lugar del concubinato. Aunque su situación material sea precaria respecto al rival, él encarna cierta respetabilidad, o mejor dicho, una mayor conformidad a las convenciones sociales. Las bromas entre Péricles y el falso "Sócrates” sobre la Grecia antigua se reducen a un intermezzo cómico, sin establecer la rivalidad basada en la inteligencia (ni la edad). Por el contrario, al convocar al antiguo patrón, sin saber que se trata del padre de Richardson, Mario Alvarez antepone la venganza al amor, a los ojos de la decepcionada Nancy. Solo cuando él le revela su doble identidad, por medio de una flor-amuleto entregada al viejo Mendigo, la mujer recapacita. Acto seguido, en el umbral de la iglesia, Mario aparece sin la barba postiza, con un aspecto intermedio, ni elegante ni andrajoso. Su reflexión, a modo de moraleja, tampoco fue escrita por Joracy Camargo: “Los sentimientos son más fuertes que todas las teorías”. Una 
procesión a la Virgen entra al templo. El Mendigo confiesa que nunca había rezado antes. El desenlace del film equivale pues a una conversión, a una doble redención de dos pecadores: ella le devuelve el dinero y las joyas; él a su vez se las ofrenda a la Virgen.

El melodrama de Argentina Sono Film rescata la fuerza de los sentimientos, algo que no cuadra con la "filosofía” de Deus lhe pague: “Amor, odio, saudade, egoísmo, honor, carácter y la propia caridad de la que vivimos, son fantasías que andan por ahí dificultando la vida, cuando la vida es tan sencilla. Vivir es solo respirar, comer, beber y dormir”, dice el sentencioso Mendigo (56). Fiel discípula del viejo, Nancy asegura: "Todas las mujeres quieren a otros... Yo... sólo quiero a mí misma... Sólo el amor logra perturbar la felicidad. Y la mujer debe amar, necesita amar, no puede rehuir ese sentimiento... ¡Sólo es feliz quien ama a sí misma!” (75). Menos aún encaja en la comedia brasileña la respetuosa religiosidad de la versión filmada en los estudios porteños.

La adaptación cinematográfica confiere un lugar central a la religión, desde la misma organización del espacio — basta cruzar la calle para encontrar en ambas veredas las disyuntivas entre las que oscila la mujer: el casino y la iglesia, el antro del vicio y el templo de la virtud. Igual ocurre con la construcción dramatúrgica y el desenlace al pie del altar, en plena misa: la comunión de los fieles y el acto de caridad se confunden, el desprendimiento sella la reconciliación de la pareja. Si bien una nota del autor recomendaba la utilización de "música litúrgica”, sobre todo al final, en el teatro Deus lhe pague no transpone el umbral de la iglesia, no hay ninguna clase de “conversión” del Mendigo. En la pieza existe casi una unidad de lugar, puesto que el decorado donde vive el obrero y la mansión del millonario surgen por efectos de iluminación, solo para situar las sucesivas peripecias. El dispositivo espacial que pone frente a frente el templo de la redención y el antro del pecado no sólo es absolutamente extraño a las intenciones de Joracy Camargo, sino que introduce las típicas polarizaciones melodramáticas del bien y el mal. El “apólogo filosófico” se transforma en parábola religiosa.

La religión era uno de los temas discutidos entre el Mendigo y el Otro, contribuyendo a fundamentar el relativismo racionalista que impregna el texto original. Mientras la comedia de Joracy Camargo pretendía exaltar la racionalidad de una inteligencia superior, la película entronca con la tradición religiosa del melodrama latinoamericano. Las nociones de redención y conversión son típicas del pathos melodramático y ajenas al arsenal cómico. Al mismo tiempo, Dios se lo pague es un melodrama que encuentra buena parte de su interés en las brillantes réplicas y reflexiones de una dramaturgia basada en las frases de efecto y no solo en los coups de théâtre del drama decimonónico. La comicidad no desaparece en la película, pero se integra a una estructura decididamente melodramática, subrayada por el patetismo del flash-back y la solemnidad litúrgica del desenlace. En la pieza brasileña, no existe ningún vínculo de familia entre los principales personajes, no hay filiación entre Péricles y el antiguo patrón abusivo que explica el desdoblamiento del falso Mendigo. Tampoco se suicida la mujer engañada por el empresario, conforme ocurre en la pantalla. En Deus lhe pague, el deseo de venganza no mueve al protagonista, que limita su revancha sobre la sociedad a sus invectivas "filosóficas".

En el cine clásico, los resultados no dependen de la personalidad del director, sino que pasan por la conjunción armoniosa de los valores de producción y las convenciones de género. No obstante, Luis César Amadori (Pescara, Italia, 1902-Buenos Aires, 1977) 
es el nombre con mayor relieve en los créditos y resume bien la fluida circulación entre las principales formas del espectáculo porteño, el teatro, la música y el cine, que concurren al éxito de Dios se lo pague. Propietario del Teatro Maipo, uno de los templos de la revista musical, estratégicamente ubicado en la calle Esmeralda entre Corrientes y Lavalle, Amadori compuso tangos en colaboración con Discépolo, Canaro, Charlo, Malerba y Rubinstein (Ferrer 251). La música ciudadana es sensible al entorno social, aunque carezca de la entidad atribuída por la película a Wagner o Schubert. La esmerada producción de Argentina Sono Film combina los impecables decorados del refugiado español Gori Muñoz, una eficaz iluminación y fotografía de Alberto Etchebehere con un vestuario y maquillaje de la rubia Zully Moreno (Nancy) que recuerdan la moda y el aspecto de Eva Perón: aparte de la iconografía política de la época, el personaje femenino de Dios se lo pague también evoca a Evita por su trayectoria de la vida ligera a la beneficiencia. Medio siglo después, la exaltación de la caridad no está demasiado alejada de las propuestas actuales de condonación de la deuda de los países pobres (el socialcristianismo a menudo reencarnado en las ONGs), aunque en la película refleje bien la ideología asistencial del peronismo. La hipocresía de las caritativas damas, denunciada por el protagonista de Dios se lo pague, remite al conflicto entre la alta sociedad porteña y Eva Perón, cuando ésta empezó a concentrar en instituciones oficiales las acciones de bienestar social (en 1948, justamente, se crea la Fundación Eva Perón).

Según Clara Kriger, “el deseo de conciliar posiciones entre el capital y el trabajo”, ${ }^{11}$ característico del peronismo, encuentra una encarnación paradigmática:

En Dios se lo pague, el cuerpo del protagonista, Mario Alvarez (Arturo de Córdova), es el recipiente que une dos condiciones sociales antagónicas, un burgués acomodado de día y un mendigo miserable de noche. Su trayectoria en el film no será otra que la de lograr conciliar internamente los dos mundos a los que pertenece. En el comienzo, estas dos versiones de la misma persona se hallan en conflicto permanente, el mendigo afirma que "honestidad y decencia son mentiras burguesas," ya que ellos "viven del trabajo ajeno" y no "terminan en la cárcel”. Recordando su pasado, nos informa que ha sido un obrero (“cuando todavía no se habían inventado las leyes de protección obrera”) engañado por empresarios sin escrúpulos que provocaron su ruina. Pero esa dicotomía irá desapareciendo hacia el final del film, cuando decide concretar su venganza y unificar los dos mundos en los que vive, convirtiéndose en dueño de una empresa pero sin olvidar que hay que "dar lo que se tiene y pedir lo que se desea (Kriger, "Dios se lo pague” 85-88).

Si bien el suspense final depende de la decisión de Nancy, estamos frente a un melodrama estrictamente masculino, muy sintonizado también con el caudillismo populista y el rol supuestamente protagónico de la mujer, un papel en realidad subordinado como el de Evita, cuando no decorativo: el derecho de voto del “segundo sexo” en la Argentina fue adoptado por ley en 1948 (año del estreno de Dios se lo pague), pero se hizo efectivo en la elección de 1951, cuando Eva Perón tuvo que renunciar a su candidatura a la

${ }^{11}$ Véase: Kriger, “El cine del peronismo” 144-45. La fortuna crítica póstuma de la película es más bien reservada: apenas unas líneas le están dedicadas en el opúsculo reivindicativo de Claudio España, Luis César Amadori. 
vicepresidencia. Ambos personajes femeninos, absolutamente esquemáticos, de una sola pieza, encarnan la pasividad. Cuando toman una iniciativa, precipitan el drama: la esposa del obrero traiciona sus intereses y entrega su secreto al patrón, la amante de la vida fácil pretende abandonar al hombre que le brindó un lugar en la sociedad por un estafador. En cambio, la riqueza de la figura interpretada por Arturo de Córdova es tal, que lo obliga prácticamente a encarnar tres personajes: el obrero, el mendigo y el millonario. El segundo pordiosero, su discípulo, es casi un desdoblamiento del protagonista. El conflicto por la belleza femenina opone dos formas distintas de masculinidad, transformando a la hembra en juguete, mientras a los hombres les reserva el papel de motores del drama. La apariencia resume la esencia de la mujer, lo que no ocurre con los dos arquetipos masculinos, contrapuestos por el carácter (cálculo intelectual y entereza moral versus parasitismo e irresponsabilidad). El discurso del Mendigo destila misantropía y misoginia en dosis desiguales: las responsabilidades de los individuos se diluyen en la responsabilidad mayor de la sociedad, pero nada viene a disminuir la insensatez femenina. En la fiesta, hombres y mujeres son igualmente hipócritas, todos encarnan un rol social, pero mientras las hembras son pedigüeñas, los hombres se juegan el dinero. En la puerta de la iglesia como en la mesa de juego, en la fábrica como en la mansión, todo gira alrededor del poder del dinero, confirmando la supremacía masculina.

Aunque una serie de aspectos remitían al espectador argentino de la época al discurso y a la iconografía peronistas, la ambientación descontextualiza la ficción, situándola en una urbe genérica, sin particularismos nacionales, de acuerdo a la estrategia exportadora. Así y todo, el Club de Residentes simbólicamente situado frente a la iglesia, remite al Club de Residentes Extranjeros, el primer centro social creado en Buenos Aires, a mediados del siglo xix. Y el apellido Richardson evoca a la importante comunidad inglesa (el peronismo nacionalizó los ferrocarriles británicos).

A la contribución de Argentina Sono Film y a la pieza del autor brasileño se suma Arturo de Córdova (1908-1973), la estrella masculina mexicana con mayor carrera internacional (filmó en Hollywood, Venezuela, Brasil y España). La elección del protagonista es significativa, pues simboliza un México moderno, cosmopolita, donde el nacionalismo revolucionario ha sido definitivamente institucionalizado, domesticado, congelado. En cambio, Jorge Negrete (1908-1953) y Pedro Armendáriz (1912-1963) estaban identificados con un México prerrevolucionario, rural e indigenista, con la “añoranza porfiriana”, según la terminología inventada por Ayala Blanco (si bien nuestra tipificación es injusta con Armendáriz, que mostró una versatilidad comparable a la de Arturo de Córdova) (40-47). Pedro Infante (1917-1957), el más joven y carismático de los cuatro, había cumplido recién treinta años, insuficientes tal vez para las dos vidas sucesivas encarnadas por el doble protagonista de Deus lhe pague (aunque Procópio Ferreira la estrenó con 34 años).

En lo ideológico, la transformación de la comedia de Joracy Camargo en melodrama de Argentina Sono Film muestra la amplia circulación de las tesis sociales del populismo latinoamericano, de Vargas a Perón, sin olvidar al nacionalismo mexicano. Así como el obrero se volvió mendigo por un artilugio varguista, gracias al peronismo el trabajador se transforma en descamisado; el primero filosofa a la buena de Dios, mientras el segundo vota a “San Perón”. En ambos casos, el desclasado conjura el fantasma de un proletariado 
organizado. Tal vez podamos atribuir la mayor irreverencia de la pieza a la efervescencia de los años treinta, cuando el populismo aún busca su lugar y perfil a través de sucesivos reacomodos institucionales, mientras la película refleja la consolidación estatal de posguerra. Entre la Revolución del treinta, la intentona comunista de 1935 (el fracasado golpe militar organizado por el PCB), el Estado Novo de 1937 y la democratización de 1945, Brasil busca penosamente la estabilidad. En México, el Jefe Máximo, Plutarco Elías Calles, domina hasta la elección del general Lázaro Cárdenas, que nacionaliza el petróleo e impulsa la reforma agraria: el Partido Revolucionario Institucional sólo merece su nombre definitivo en 1946, con la elección de Miguel Alemán, civil y católico, después de décadas de caudillos militares y persecuciones antirreligiosas. En la Argentina, también, las dos presidencias de Juan Domingo Perón representan un mínimo de continuidad gubernamental, por primera vez desde 1930. En los tres países, la unción de la Iglesia católica fue fundamental en el período inmediato a la posguerra: las necesidades del melodrama iban de la mano con las conveniencias políticas.

Según el testimonio de Procópio, Getulio Vargas (en el poder, como dijimos, de 1930 a 1945) fue a ver Deus lhe pague en el teatro unas diez veces. Al asistir al ensayo general, el mismísimo censor Armando Pamplona le dijo a Procópio: “es una pieza genial” (Procópio Ferreira apresenta Procopio 241). Dos anécdotas confirman la identificación del caudillo gaúcho y su entourage con la pieza. Marabá, otra obra de Joracy Camargo, puesta en escena en 1934, fue prohibida por la censura, porque según el mismo Procópio “era absolutamente comunista, abiertamente comunista”. El actor fue convocado por el jefe de policía, el temido Felinto Müller, que lo conminó a que la reemplazara por... Deus lhe pague. En Portugal, en 1935, la censura de Salazar pretendía prohibirle a Procópio que presentara su mayor éxito. El asunto casi provoca un incidente diplomático, resuelto por la firme intervención de la Presidencia brasileña en defensa de Deus lhe pague. ${ }^{12}$

En cuanto a la película Dios se lo pague, fue plenamente endosada por el peronismo, no sólo al representar a la Argentina en Venecia y junto a la Academia de Hollywood, sino sobre todo al ser elegida para inaugurar el primer festival de cine argentino de Mar del Plata, el 16 de marzo de 1948 (cinco días después del estreno en la Capital Federal), bajo la presidencia del coronel Domingo Mercante, gobernador de la provincia de Buenos Aires (y testigo de matrimonio de Juan Domingo Perón y Eva Duarte). El enviado especial del diario carioca $O$ Globo, aparte del orgullo de ver a un nombre brasileño (Joracy Camargo) asociado al primer festival, expresa su confianza en "el cine argentino, ya tan

\footnotetext{
${ }^{12}$ Véase: Ferreira, Depoimentos I 100-101, 109-10. Vargas creó el Servicio Nacional del Teatro, así como otras instituciones culturales, gracias a la cooptación de intelectuales modernistas en la administración del ministro de Educación, Gustavo Capanema. Una hija de Procópio, Ligia Ferreira, afirma que su padre estuvo afiliado al Partido Comunista Brasileño, algo poco probable (Barcellos 39-40). El éxito de la temporada lusitana desembocó en una de las primeras apariciones de Procópio Ferreira en la pantalla, Trevo de quatro folhas (Chianca de Garcia, Sonarte [Lisboa], 1936), un film desaparecido (Pina 69 y ss). El portugués Chianca de Garcia sería contratado a su vez por la Cinédia de Adhemar Gonzaga para dirigir el mencionado Pureza (1940, inspirado en una novela de José Lins do Rêgo) y 24 horas de sonho (1941), a partir de un argumento de Joracy Camargo, primeros pasos de su radicación en Brasil.
} 
pujante y ahora incorporado al plan quinquenal de liberación industrial, económica y artística del Gobierno Perón”. ${ }^{13}$

Si bien la actriz argentina Zully Moreno tuviera todas las razones del mundo para ser la elegida (era una figura consagrada y Amadori la había desposado justo antes del rodaje), la opción por una rubia en lugar de una morena contribuye sin duda a la desterritorialización y al cosmopolitismo, sin el menor sacrificio a la identificación del espectador local: en el star system porteño predominan las trigueñas, mientras en el mexicano ocurre lo inverso. ${ }^{14}$ El público de los tres países latinoamericanos más populosos podía regocijarse de reconocer algo suyo en la pantalla — para los brasileños, era la consagración internacional del mayor éxito del teatro nacional—, sin que eso excluyera al vecino ni fuera un obstáculo para los demás. Dios se lo pague reúne pues a valores de los tres principales países de América Latina, en un esfuerzo por sumar bazas y aumentar sus posibilidades en el mercado internacional. A la estrategia transnacional del proyecto corresponde la transformación de la pieza original y la hibridación del resultado.

La pareja protagónica mexicano-argentina volvió a reunirse con éxito en Nacha Regules (1950), otro melodrama social, filmado en los mismos estudios porteños, y en María Montecristo (1950), rodado en los estudios Azteca (México), ambos dirigidos por Luis César Amadori. Argentina Sono Film perseveró en su estrategia: Atilio Mentasti contrató acto seguido a la estrella mexicana Dolores del Río para Historia de una mala mujer (Luis Saslavsky, Argentina, 1948), basada en El abanico de Lady Windermere de Oscar Wilde, adaptado varias veces a la pantalla (Ernst Lubitsch, 1925; Otto Preminger, 1949).

Dios se lo pague batió el récord de recaudaciones del cine argentino hasta entonces, sumando los ingresos dentro y fuera del país (Di Nubila 93). En México, la película se mantuvo cinco semanas en la sala de estreno, lo que la sitúa entre las más exitosas del año. ${ }^{15}$ En Río de Janeiro, tuvo un estreno excepcional en ocho salas y permaneció en cartelera por lo menos siete semanas. En São Paulo, el impacto se repite, con seis salas de primera línea. En Porto Alegre, Dios se lo pague se proyecta en dos cines durante dos semanas, “un

\footnotetext{
${ }^{13}$ Edmundo Lys, “Deus lhe pague inaugurou o festival de Mar del Plata: A versão cinematográfica da peça de Joracy Camargo abriu as sessões fílmicas do certame - Um êxito, a realização dos produtores vizinhos”, O Globo, Río de Janeiro, 17 de marzo de 1948. Se trata por supuesto del festival nacional, el certamen internacional surge recién en 1954, durante el segundo mandato de Perón. Las referencias de la prensa brasileña sobre Dios se lo pague se encuentran todas en el archivo del productor Adhemar Gonzaga, conservado en los estudios de la Cinédia (Río de Janeiro). Agradecemos las fotocopias a Hernani Heffner y a Gilberto Santeiro (Cinemateca del Museo de Arte Moderno de Río de Janeiro).

${ }^{14}$ Véase Paranagua, "L’Amérique Latine, des velléités aux mythes".

${ }^{15}$ Apenas 17 títulos, de un total de 445, estuvieron cinco o más semanas en cartel en las salas de estreno de Ciudad de México. De los 17 mencionados, 4 son mexicanos, 8 norteamericanos, 3 europeos y 2 argentinos (el segundo es Corazón, otro melodrama, basado en la novela de Edmondo d'Amicis, dirigido por Carlos Borcosque, 1947). Triunfan en el Distrito Federal tanto las producciones mexicanas prestigiosas (Maclovia, Emilio Fernández), como las películas netamente populares: la comedia anual de Cantinflas, el melodrama tremendista Nosotros los pobres (Ismael Rodríguez) y el costumbrismo populista de iEsquina bajan! (Alejandro Galindo) (Amador y Ayala Blanco 313, 390-91).
} 
nuevo record en la cinelandia local” ${ }^{16}$ El éxito de la adaptación cinematográfica dio un segundo aliento a la pieza original. Joracy Camargo habla con entusiasmo de nuevas puestas en escena en Francia, Italia y España, "gracias a la divulgación hecha por la película”. ${ }^{17}$ Procópio siguió interpretándola a lo largo de las décadas de los cuarenta y cincuenta, con un último montaje en 1968.

Sin embargo, la recepción de la crítica brasileña revela controversias. El muñequito del diario O Globo aplaudió sentado: aunque el "bonequinho” no se puso de pie, consideró que Dios se lo pague "honra al moderno y adelantado cine argentino”. La adaptación le pareció “primorosa”, “sin traicionar el original”, "no podía ser más feliz la adaptación (...). Conservando toda la esencia del original, adquirió valores cinematográficos”. ${ }^{18}$ Tampoco la Folha da Tarde de Porto Alegre escatima los méritos del film: “otra victoria brillante, indiscutible, del cine argentino. Es necesario decir aquí el elevado nivel técnico y artístico alcanzado desde hace mucho por la industria fílmica de Buenos Aires”. El diario gaúcho elogia asimismo "la forma inteligente en que fue aprovechada la historia de Joracy Camargo, que gana en la pantalla nueva vida, nuevo interés, que a menudo no logra alcanzar en el palco”. ${ }^{19}$ Una publicación paulista, Radar, está de acuerdo: “el cine argentino marcó un tanto”. Nadie cuestiona el derecho e incluso el interés de que sea una industria de otro país la encargada de llevar a la pantalla el taquillazo del teatro brasileño. Prevalece entonces una conciencia aguda de la incapacidad de la producción local para emprender grandes proyectos (otro estado de ánimo muy distinto, a diez años de distancia, explica las reticencias brasileñas frente al Orfeu negro del francés Marcel Camus, 1959, a pesar de estar filmado en Río). A lo sumo, el cronista Paulo de Alencar confiesa: “Dios se lo pague llega a despertar, incluso en los corazones más empedernidos, una punta de melancolía y —¿ ¿por qué no? - un velo de resentimiento al recordar el cine nacional”. ${ }^{20}$

No obstante, “el espíritu de la pieza es uno y el de las imágenes es otro”, escribe el crítico Jonald. “Tantas fueron las alteraciones introducidas en la pieza de Joracy Camargo, que el sentido general quedó un tanto sacrificado. Sin embargo, a pesar de la supremacía de los diálogos, el conjunto revela un nivel satisfactorio”. ${ }^{21}$ La revista $O$ Cruzeiro adopta una postura parecida: “aunque básicamente disociada de la pieza de Joracy Camargo (lo que no importa en términos de lenguaje cinematográfico), Dios se lo pague todavía conserva resquicios de teatro, pero no deja por ello de ser un buen film”. Después de confesar que no esperaba nada de un cine argentino que "aún está gateando” a pesar de su nivel técnico, el crítico del importante semanario admite que se trata de la mejor película argentina después de La guerra gaucha (Lucas Demare, 1942). ${ }^{22}$ Aunque no hubiera visto

16 Según un artículo del diario Folha da Tarde, Porto Alegre, 6 de julio de 1949. Las demás informaciones sobre Brasil provienen de recortes de prensa del archivo de Adhemar Gonzaga.

${ }^{17}$ F.C.M., "Cinco minutos com Joracy Camargo," Radar (São Paulo, 21-27 de junio de 1949) (Archivo Adhemar Gonzaga).

${ }^{18}$ Fred Lee, "Deus lhe pague,” O Globo (Río de Janeiro, 7 de abril de 1949) (Archivo Adhemar Gonzaga).

19 “Deus lhe pague,” Folha da Tarde (Porto Alegre, 6 de julio de 1949) (Archivo Adhemar Gonzaga).

${ }^{20}$ Paulo de Alencar, “Deus lhe pague,” Radar (São Paulo, 3 de mayo de 1949) (Archivo Adhemar Gonzaga).

${ }^{21}$ Jonald, “Deus lhe pague,” (Río de Janeiro, 7 de abril de 1949) (Archivo Adhemar Gonzaga).

22 José Amadio, O Cruzeiro (Río de Janeiro, 23 de abril de 1949) (Archivo Adhemar Gonzaga). 
la pieza, al decano de la crítica carioca, Pedro Lima, tampoco le gustó la "secuencia religiosa, buena para cierto público, pero fuera de propósito para un film de finalidad tan diferente. En todo caso, hay que subrayar el esfuerzo del cine argentino en llevar a la pantalla un original brasileño, con artistas de renombre y un tratamiento de clase”. ${ }^{23}$

La melancólica conclusión de Paulo de Alencar merece un desarrollo explícito de otro paulista, José Carlos: "no se puede exigir del cine argentino un nivel técnico y artístico que se equipare al de las industrias fílmicas de Estados Unidos, Gran Bretaña y Francia. Urge que el público paulista, que ha sido tan tolerante con el cine de Brasil, también encare la progresista industria cinematográfica del Río de la Plata con benevolencia”. Aparte de asegurar que los argentinos son "gente muy simpática y generosa; al contrario de lo que mucha gente equivocadamente piensa, son amigos sinceros y admiradores de Brasil”, el periodista advierte: "hay mucha mala fe y animosidad, por lo tanto, en esta guerra sorda que aquí se mueve contra las películas porteñas. Sobre todo en este principio de campaña contra Dios se lo pague..."24

Por lo visto, la referida guerra no se molesta en adoptar la sordina. Jorge Ileli empieza su crítica con las siguientes palabras: "Un film argentino parece un tango: plañidero, desdichado, nostálgico y romántico”. Ileli considera la preferencia por el melodrama "capaz de conducir al cine argentino hacia un camino equivocado". El cine brasileño prefiere la comedia, género apreciado por el futuro realizador Jorge Ileli. En su opinión, "la adaptación cinematográfica de Tulio Demicheli está hecha con sentido de cine, pero traiciona su origen”. A pesar de insistir en el fondo social de la pieza original, el autor de esas líneas apunta en otra dirección: la película "no consigue ocultar el origen teatral de la obra. Su mayor valor sigue siendo el texto. La originalidad del asunto y la fuerza de los diálogos dan consistencia al film y el mérito pertenece, en gran parte, a Joracy Camargo”. El crítico del periódico de izquierda Diretrizes aún tiene otro reproche: "La dirección de Luis César Amadori puede ser considerada buena (...). Su error imperdonable reside en la modificación del final de la pieza de Joracy Camargo, desvirtuando el mensaje para ser agradable al clero. Fue una concesión absurda e injustificable. No solamente fue modificado el mensaje. El propio fondo fue parcialmente alterado”. Y todo en nombre de un "americanismo enervante”, según el ulterior director de un documental hagiográfico sobre el varguismo, No mundo em que Getúlio viveu (Jorge Ileli, Brasil, 1963). ${ }^{25}$

Sin embargo, el nacionalista Ileli está lejos de ser el más severo. Desde el catolicismo conservador, la derecha antipopulista o la izquierda dogmática, surgen críticas que parecen rebasar el solo caso de Dios se lo pague. En la crítica católica aún empeñada en dirimir la cotación moral de las películas, encontramos una arremetida contra el argumento folletinesco de la película: el adaptador "no consiguió quitarle el tono teatral. Y tomen diálogos. La filosofía comunizante y fácil del sr. Joracy Camargo tenía que ser expuesta.

\footnotetext{
${ }^{23}$ Pedro Lima, “Deus lhe pague,” O Jornal (Río de Janeiro, 9 de abril de 1949) (Archivo Adhemar Gonzaga).

${ }^{24}$ José Carlos, “Deus lhe pague,” Diario da Noite (São Paulo, 29 de abril de 1949) (Archivo Adhemar Gonzaga).

${ }^{25}$ Jorge Ileli, “Deus lhe pague,” Diretrizes (Río de Janeiro, 7 de abril de 1949) (Archivo Adhemar Gonzaga).
} 
Y tomen diálogo. La cuestión del patrón malo y del buen obrero tenía que ser presentada como problema social. Y tomen dialéctica...” Aunque el happy end termine "incluso con una bendición del Santísimo”, el inquisidor no se deja convencer: “¿Habrá el millonariocomunista Joracy Camargo aceptado así sin protesta o reluctancia un final tan disconforme con su filosofía de la línea justa?’26

Justamente, los partidarios de la ortodoxia se hacen la misma pregunta. Carlos Ortiz considera Dios se lo pague "pésimo cine”. La obra de Joracy Camargo fue "tremendamente estropeada, exactamente donde la pieza de teatro poseía más fuerza y sentido polémico”. Ortiz critica los diálogos prolongados, la construcción teatral, "las lecciones de socialismo utópico en la puerta de una iglesia”. Pero no soporta aquel "final barroco y ñoño, en un rezo de mes de mayo, con la conversión edificante del mendigo millonario. Amigo Joracy, ¿Cómo permitiste que deturparan la letra y el espíritu de tu famoso Deus lhe pague?”27

Antonio Moniz Vianna estaba entonces empezando su larga trayectoria crítica, pero a los veinticinco años ya pontificaba como lo hará luego frente al Cinema Novo:

El cine argentino sigue siendo un problema sin solución. Por más que nos sintamos predispuestos a aceptarlo, no lo podemos hacer sin transigir. El mexicano evoluciona y nos da obras de considerable belleza e importancia (...). El argentino responde a México -la analogía nace del idioma que los une y los vuelve rivales en términos comercialescon cintas inferiores, pero ambiciosas, y Dios se lo pague no es más que una réplica débil de quien no puede, aunque desea, sostener polémica. Ya no hablo de la técnica en sí, que uno y otro tienen en buen nivel, sino de la manera de usar esa técnica. El argentino la usa para dar contornos a cuanto dramón negociable exista. El mexicano también produce sus dramones. Es lo malo —o la concesión, que es un mal terrible — del cine latino, al que están sujetos hasta el italiano y el francés. Pero ese mal se agrava en el cine latinoamericano. Hay una especie de tropismo positivo hacia la ñoñería, en la Argentina y en México (...). Dios se lo pague no escapa a la tendencia que se viene observando (...) de crear un cine sin personalidad, sin vida interior, sin belleza. La evolución técnica notada en el film de Luis César Amadori no atenúa esa impresión. No es la encuardenación en cuero con letras doradas la que hace un buen libro (...). Sin técnica no se concibe una pieza de arte. Pero la técnica solamente tampoco la hace (...). La película no es nada, ni película es, pero no digan eso delante de Perón. Nacionalismo excesivo - aunque con temas extranjeros - ahí está en lo que se debate el cine argentino y ahí está resumido lo que vendrá a perderlo, si es que no lo ha hecho ya. ${ }^{28}$

Aparte del estilo mordaz, característico de uno de los críticos más incisivos y personales de la prensa brasileña, el texto de Moniz Vianna es una toma de posición acerca de los dilemas de la cinematografía latinoamericana en general (el título del artículo es “el film argentino”). Cabe recordar que fue un enemigo implacable de la chanchada carioca,

\footnotetext{
${ }^{26}$ Fan $n^{\circ}$ 1, Diario de Belo Horizonte (8 de mayo de 1949) (Archivo Adhemar Gonzaga).

${ }^{27}$ Carlos Ortiz, "Deus lhe pague," Folha da Manhã (São Paulo, 8 de mayo de 1949) (Archivo Adhemar Gonzaga). Poco después, Ortiz fue el crítico del periódico Noticias de Hoje y de la revista Fundamentos, ambos del PCB.

${ }^{28}$ [Antonio] Moniz Vianna, “O filme argentino,” Correio da Manhã (Rio de Janeiro, 9 de abril de 1949) (Archivo Adhemar Gonzaga).
} 
lo que no autoriza a interpretar su rechazo al melodrama como una preferencia por la comedia. Tampoco sería justo achacar su severidad a un reflejo de defensa del cine brasileño frente a sus competidores del continente, porque pocos críticos fueron tan exigentes con la propia producción nacional. Quizás sí pudiera verse en filigrana su gusto por el cine clásico norteamericano en su vertiente menos sentimental, en una coyuntura de renovada influencia italiana y francesa. En todo caso, sería demasiado fácil descartar sus incómodas observaciones en nombre de una evidente antipatía hacia el peronismo.

La estrategia transnacional de Atilio Mentasti y Argentina Sono Film no arrojó los resultados esperados, más allá del ámbito iberoamericano. Aunque el historiador Domingo Di Núbila mencione recaudaciones en México y Estados Unidos superiores al costo de la película, ${ }^{29}$ la ausencia de reseñas en Variety y el New York Times (o de referencias en el anuario Screen World) indicaría que Dios se lo pague no llegó a los cines norteamericanos. ${ }^{30}$ Aparte de la figura y el talento de Arturo de Córdova, su elección para el papel protagónico tenía en cuenta su reciente carrera en Hollywood, aunque ésta estuviese sujeta a controversia. El actor mexicano era una baza de cara a su propio país y al resto de América Latina, pero también hacia otros mercados. Es cierto que al año siguiente Argentina y los Estados Unidos estaban enfrascados en un pleito, porque a las nuevas autoridades peronistas se les ocurrió exigir reciprocidad en los estrenos.

La candidatura al Oscar, presentada por la Argentina, no tiene siquiera el valor atribuido hoy a las nominaciones, una selección efectivamente avalada por la Academia. Tampoco tiene mayor significación el premio (o los premios) obtenidos en el Certamen Cinematográfico Hispanoamericano de Madrid, en junio de 1948. En palabras de José Luis Borau, "como se trataba de no herir susceptibilidades y de que la satisfacción fuera general, se decidió que cada uno de [los largometrajes] sólo compitiera con los de su propia nacionalidad" (207-09). Hubo pues galardones para griegos y troyanos, o por lo menos para españoles, mexicanos y argentinos, los únicos dignamente representados (estos últimos, por Miguel Machinandiarena y Angel Luis Mentasti, entre otros). En resumen, aparte de los laureles que la misma industria argentina se trenzó, Dios se lo pague pasó sin pena ni gloria por las competencias internacionales.

En España, por lo menos, sí se estrenó la película, en Barcelona el 25 de enero de 1949, en el cine Cristina (Kriger, “Dios se lo pague” 85), y en Madrid, el 23 de junio de 1949, en el Rex. ${ }^{31}$ El veterano crítico Antonio Barbero parecía acosado por las dudas:

Faltaríamos a la verdad si dijésemos que nos ha gustado esta película en su totalidad; pero no seríamos sinceros si afirmásemos que no nos ha gustado. Trataremos de explicarnos. Nos parece muy bueno el argumento; no carece de novedad y está desarrollado con muy buenos toques de humor e ironía. Pero nos parece equivocado el guión, que ha conservado

\footnotetext{
${ }^{29}$ Véase Di Núbila, 94. Los derechos sobre ambos territorios habrían sido cedidos a Arturo de Córdova, que los revendió al distribuidor Mohme.

${ }^{30}$ Internet Movie Data Base menciona God Reward You solo como "informal English title" para los EE.UU., donde la película figura como “Unrated”, es decir, sin clasificación de censura. En cambio, IMDB informa sobre la existencia de telenovelas basadas en Dios se lo pague en Colombia (1997) y quizás en Argentina (1981) y México (1990).

${ }^{31}$ Según la documentación española subsiguiente, amablemente comunicada por Alberto Elena.
} 
toda la teatralidad de la obra original, sin prescindir de los diálogos, intencionados, graciosos y hasta oportunos, pero anticinematográficos. Nos ha parecido bastante buena la dirección, que ha salido triunfante de su desigual lucha con una adaptación que no adapta nada, ni aclara muchos pasajes confusos; y, sin embargo, en Dios se lo pague existe una dignidad y unas calidades cinematográficas que la diferencian de un modo notable de lo que despectivamente llamamos teatro fotografiado. ${ }^{32}$

Otra reseña dubitativa sugiere resquemor hacia la problemática social, estrechamente controlada por la censura franquista: "El cine argentino, en esta película, denota preocupación por los temas de altura, sin recatarse tampoco de hacer una intencionada crítica social. La tesis de Dios se lo pague es diáfana, pero al pasar por el guión ha perdido fuerza y unidad. En todo el film hay un diálogo elaborado con profunda filosofía, que convengámoslo, no es cine, sin que por ello deje de gustar...”33 Otra nota de la prensa especializada ve antes que nada la revelación de "un gran intérprete: Arturo de Córdova”, ${ }^{34}$ sin recordar, por supuesto, su papel en ¿Por quién doblan las campanas? (For Whom the Bells Toll, Sam Wood, EE.UU., 1943), adaptación de la novela de Hemingway non grata en la España de posguerra.

Sin embargo, la revista más oficialista, directamente vinculada al aparato de propaganda falangista, Primer Plano, no disimula el entusiasmo e incluso arriesga consideraciones generales que valen también para el cine español en ciernes:

\begin{abstract}
Hemos visto un cine argentino tan escaso generalmente de calidad o tan preocupado por el esteticismo — dos extremismos que son las enfermedades infantiles de las más jóvenes cinematografías-, que la aparición de una cinta como Dios se lo pague induce a algunas consideraciones generales. La más importante es que hay que quitarse el sombrero ante el esfuerzo que en todos los órdenes se ha tenido que realizar allí para llegar desde los lamentables engendros que tantas veces hemos visto como "cine argentino," hasta esta, relativamente reciente, producción, de cuya perfección no caben dudas. Gran película, con lo que queremos significar que la calidad no es sólo técnica, sino interpretativa, de realización y argumental. Especificando, creo que lo más importante es la originalidad del argumento de Joracy Camargo. Más de una vez la visión del mundo, según la filosofía de los vagabundos, se ha asomado a la pantalla. (...) El mendigo de Dios se lo pague constituye en realidad el motor de una intriga, que se desarrolla y evoluciona según ángulos de sorpresa ininterrumpida, mientras Barata es la picaresca desnuda. Y el diálogo de los dos a la puerta de la iglesia y el club quedará como algo que hubiera firmado René Clair, aunque es posible que Clair hubiera dejado hablar a la imagen, y el cine argentino, por aquello de la raza, prefiere que hable la palabra..$^{35}$
\end{abstract}

Aparte de comprobar la circulación de las tesis sociales del populismo latinoamericano, Dios se lo pague ejemplifica asimismo la convergencia ideológica entre el peronismo y el falangismo. En las salas de cine donde poco después se proyectaría la película, las

\footnotetext{
${ }^{32}$ Antonio Barbero, "Dios se lo pague”, Cámara, año IX nº 156 (Madrid, 1 de julio de 1949): 9.

33 "Dios se lo pague”, Imágenes, año V n 45 (Barcelona, marzo de 1949).

34 "Dios se lo pague”, Fotogramas, año IV n 54 (Barcelona, 1 de febrero de 1949): 20.

${ }^{35}$ Luis Gómez Telles, “Dios se lo pague”, Primer Plano, año X n 455 (Madrid, 3 de julio de 1949).
} 
imágenes del noticiero español No-Do ofrecieron amplia constancia de la alianza entre Franco y Perón, así como de la triunfal visita de Evita a España. ${ }^{36}$ A pesar de cierto desfase en el tiempo, en España se reproducía la complementaridad entre documental y ficción, cuya yuxtaposición y suma permitía interpretar cabalmente las sugerencias de la proyección cinematográfica en su contexto original, la Argentina peronista: lo no-dicho o lo alusivo de Dios se lo pague, lejos de permanecer fuera de campo, encontraba su explicitación introductoria en la misma pantalla, a través de las imágenes de propaganda, legitimadas en su "veracidad” por su propio caracter “documental”.

En Francia, el film se distribuyó recién unos años después, a la vez en versión original subtitulada y en versión doblada, lo que supone la expectativa de llegar a un público amplio, popular. Le Mendiant de minuit se estrena en París el 6 de junio de 1952, permaneciendo dos semanas en cartelera en el Normandie (situado en los Campos Elíseos, 1.632 localidades) y el Rex (ubicado en los Grandes Bulevares, 3.292 butacas, la segunda mayor capacidad de la capital, justo después del Gaumont Palace). La taquilla debe haber decepcionado al distribuidor, Les Films Marceau, que obtuvo salas de tanto prestigio. El Normandie atrae 4.590 espectadores la primera semana, 2.884 la segunda; el Rex reúne primero 14.859 espectadores y luego 10.762. En total, 33.095 personas fueron a ver Dios se lo pague en la capital francesa, un número modesto en aquellos tiempos. Para tener un punto de comparación, la cifra más elevada, la del estreno en el Rex, está muy cercana a la peor semana de la temporada en esa sala, 14.603. Tanto el Rex como el Normandie llegan a congregar un público tres, cuatro o incluso cinco veces superior. Los taquillazos del momento en Paris suman más de cien mil espectadores en la exclusividad. ${ }^{37}$

Enseguida después del estreno, el crítico del diario Combat empezaba su reseña con algunas consideraciones generales acerca del cine argentino:

Hace unas semanas, los cineastas argentinos me confesaban que en su país, encerrado
sobre sí mismo, carecían terriblemente de guionistas. El complejo de inferioridad
sudamericano limitaba el campo de sus indagaciones, descartando cualquier relato
teñido de color local; ni indios, ni gauchos, ni peones. ¡Cómo tenían razón! El cine
argentino está reducido a reinventar un oficio, sin importarse con los tópicos, las
repeticiones, el ridículo y la puerilidad. Uno puede, si quiere, enternecerse con los
primeros pasos vacilantes de este bebé; el hecho de que disponga de material perfeccionado
para aprender a caminar no obsta que sea incapaz de disputar una partida. Por ahora, sigue
en el estilo Montéhus, o sea, las eternas variaciones del mito de Montecristo, los malvados
ricos, los pobres valerosos, los pobres enriquecidos que se vengan de los ricos que se
vuelven pobres a su vez. Es como para echarse a llorar. Una prudencia elemental (si a uno
le gustaran los juegos de palabras podría incluso decir alimentaria) lleva sin embargo a
precisar: cuando el buen obrero fue frustrado de su patente por el malvado patrón, eso
ocurría en el antiguo gobierno. ¡Nada de historias con la familia Perón! ${ }^{38}$

${ }^{36}$ Las referencias del viaje de Evita (1947) y del protocolo Franco-Perón (1948) figuran en el programa Iberoamérica en las imágenes del No-Do (Madrid: Casa de América, 1996): 22-24 (gracias a Teresa Toledo).

${ }^{37}$ Datos de Le Film Français (París) del 20 de junio de 1952 (18), 27 de junio de 1952 (11) y 18 de julio de 1952 (8).

${ }^{38} \mathrm{R}$ [odolphe]-M[aurice] Arlaud, “Le Mendiant de minuit, L’éternel Montéhus,” Combat (París, 7 de junio de 1952). Aparte de la crítica, el suizo Arlaud trabajó como guionista en el cine francés. 
En el lado opuesto del espectro político, la reseña del diario conservador Le Figaro es igualmente severa: "Hay ahí algunos diálogos entre mendigos sobre la pobreza y la riqueza, un trozo de tragedia realista (el pobre diablo víctima de las intrigas de los grandes), un melodrama mundano, todo interpretado por un mismo personaje que simboliza a la vez las furias de Némesis y la sabiduría de Salomón”. El protagonista

\begin{abstract}
no busca solamente las limosnas. También busca la verdad. Nosotros lo beneficiamos un poco con ello, por supuesto. Las frases que pronuncia frente a un colega novicio, casi tan distinguido como él, son a veces significativas. Pero también son abordados temas generales: ¿Que vale la fortuna sin felicidad? ¿Y la felicidad sin la fortuna? ¿El amor puro logrará sobreponerse a las contingencias materiales? En suma, mucha filosofia, mucho problema psicológico. Uno se orienta a duras penas. Para jugar con todo ello a la vez hubiera hecho falta un autor genial. Y el Sr. Luis César Amadori no maneja con deslumbrante habilidad los resortes del pensamiento. La obra deja una impresión confusa, pesada. Su romanticismo solloza. ${ }^{39}$
\end{abstract}

El crítico francés de mayor gravitación en la posguerra, André Bazin, puede darnos la clave del fracaso, al escribir:

\begin{abstract}
Alexandre Dumas debe gozar de una respetable popularidad en la Argentina, a juzgar por su influencia indirecta en esta historia de mendigo millonario que, cada día de las 16 horas hasta la medianoche, tiende un sombrero mugriento en las puertas de las iglesias y las casas de juego, y aparece en smoking a las dos de la mañana en las recepciones que ofrece en su propia mansión. La mendicancia, ya se ve, rinde en la Argentina. Resulta que nuestro mendigo tiene dotes singulares: su conocimiento del alma de sus conciudadanos es digna de Diógenes y Sócrates, siempre sabe tan precisamente lo que hay que desearle a cada uno que las monedas llueven en el sombrero. Esa fortuna, adquirida de incógnito, le sirve primero para seducir a una mujer encantadora en búsqueda de una relación ventajosa, y luego para perpetrar una sorda venganza contra un malvado industrial que en otros tiempos le sustrajo los planos de una máquina de tejer. Nuestro mendigo, discípulo también de Arquímedes, era entonces apenas un pobre obrero. Poseedor hoy de la mayoría de las acciones de la fábrica, va a poder, a su vez, echar al capitalista a la calle. Pero tanta filosofía adquirida tendiendo la mano lo disuade y se contenta con gozar de su fortuna y de su amor hacia la bella de paso, por fin desposada. Todo esto está condimentado con barba postiza, falsa nariz y muchas verdades elementales. Un melodrama como ya no los sabemos hacer en nuestro hemisferio. Por cierto, bastante sabroso para quien se encuentre dispuesto a entrar en el juego. ${ }^{40}$
\end{abstract}

En suma, la película habría envejecido respecto al gusto del espectador francés, si interpretamos correctamente la opinión de Bazin, que escribe en un diario sumamente

\footnotetext{
${ }^{39}$ Louis Chauvet, “Le Mendiant de minuit,” Le Figaro (París, 12 de junio de 1952).

${ }^{40}$ André Bazin, "Le Mendiant de minuit, Mélo d'un autre hémisphère," Le Parisien Libéré (París, 14-15 de junio de 1952): 2. La ficha de "Le Mendiant de minuit” en $L ’ E c r a n n^{\circ} 1335$ (órgano oficial del Sindicato Francés de los Directores de Teatros Cinematográficos, L'Exploitation Cinématographique $\mathrm{n}^{\circ}$ 124, París, 1952), menciona también opiniones negativas de Franc-Tireur y Le Canard Enchaîné.
} 
popular, Le Parisien Libéré, aparte de volcar su especulación en la revista Cahiers du Cinéma y en los cine-clubs. Ya no estaban de moda los melodramas que solía producir el mismísimo cine francés, como lo recordaba el brasileño Moniz Vianna. La afición estaba evolucionando respecto a los géneros clásicos, una nueva mentalidad estaba surgiendo en los cine-clubs o en las salas de arte y ensayo, el público de antaño se estaba dividiendo. Por cierto, ni Cahiers du Cinéma, ni su rival Positif, ambas recién fundadas, ni siquiera la revista católica Téléciné, anterior, dedicaron la menor atención a la película de Argentina Sono Film.

Un libro publicado en la "época de oro" de los estudios tal vez aclare el contexto de alternativas en que se insertaba Dios se lo pague. Una editorial de Buenos Aires publicó una ambiciosa y documentada reflexión sobre el cine en una colección de ensayos que incluía títulos de Elie Faure, Thomas Mann y André Gide. El autor de Cine de hoy y de mañana es un español, Francisco Madrid, discípulo confeso de Unamuno y Ortega y Gasset. La dedicatoria menciona al productor argentino Miguel Machinandiarena y su esposa Lina, revelando la intimidad del autor con el dueño de Estudios San Miguel, que ha sido calificado como un "estudio eminentemente antifranquista" por la cantidad de refugiados republicanos que congregó. ${ }^{41}$ De Estudios San Miguel salió La dama duende (Luis Saslavsky, Argentina, 1945), adaptada de la obra de Calderón de la Barca por Rafael Alberti y María Teresa León. Lina Courtade de Machinandiarena produjo Las aguas bajan turbias (Hugo del Carril, Argentina, 1952), uno de los pocos alegatos sociales explícitos del cine peronista de ficción, basado en una novela del comunista Alfredo Varela. El mismo Francisco Madrid, aparte de su labor como crítico en el diario La Prensa y en la revista Cine, trabaja como guionista y colabora con Mario Soffici (La cabalgata del circo, Argentina, 1945), el director argentino que más elogios le merece. Por lo tanto, las especulaciones del ensayista no están desprendidas del quehacer cinematógráfico del momento; no tienen siquiera la autonomía relativa adquirida más adelante por la crítica. ${ }^{42}$ Independientemente de otras convergencias, la empresa de los Machinandiarena y la de los Mentasti estaban asociadas: Estudios San Miguel distribuye en Brasil la producción de Argentina Sono Film, reservándole un tratamiento especial a Dios se lo pague. ${ }^{43}$

\footnotetext{
${ }^{41}$ Véase Posadas ( 228). Con quien discrepa o matiza Kohen (359-60).

${ }^{42}$ Como su nombre no lo indica, aunque la lectura de su libro sí sugiere, Francisco Madrid era catalán. Su paisano Román Gubern informa que trabajó en el diario El Sol, fue corresponsal de periódicos peninsulares en París, Berlín, Ginebra y Londres, publicó las novelas Sangre en Atarazanas y Un suicida en el Hotel Ritz y un segundo ensayo: Cincuenta años de cine: Crónica del séptimo arte (Buenos Aires: Tridente, 1946). Para Benito Perojo, escribió el guión de La copla de la Dolores (Argentina Sono Film, 1947), una de las mejores películas de ambientación española filmadas en América (Gubern 66). Según Di Núbila, Francisco Madrid falleció en 1952 (159).

${ }^{43}$ Para implantarse mejor en el vecino país, Estudios San Miguel adopta otro argumento de Joracy Camargo, No me digas adiós (Luis Moglia Barth, Argentina, 1950), con interpretación binacional, e incursiona en las aventuras amazónicas con la coproducción Mundo extraño (Francisco Eichhorn, Argentina-Brasil, 1950): “Cinema argentino para o Brasil,” O Jornal (Río de Janeiro, 13 de marzo de 1949) (Archivo Adhemar Gonzaga). A su vez, Argentina Sono Film incluye a Arturo de Córdova en una intriga policiaca en la capital brasileña, Pasaporte a Río (Daniel Tinayre, 1948), que logra metamorfosear a la rubia ingénue Mirtha Legrand en femme fatale de cine negro. Tulio Demicheli,
} 
El capítulo final, “Películas nacionales y nacionalistas”, confirma la familiaridad del autor con el debate de ideas alrededor del cine en América Latina y específicamente en la Argentina, así como la voluntad de influirlo de acuerdo a sus convicciones: "Mucho se habla del destino político de la cinematografía. Algunos creen que la pantalla tiene un deber de utilidad social y política...” (133) Aunque un capítulo anterior se explaya sobre el documental y el cine pedagógico, Francisco Madrid pretende abordar la producción de ficción y

la polémica sobre la ruta que debe seguir el cine en cada país. Para unos debe estar de espaldas al exterior contemplando, únicamente, la vida de los hombres de cada tierra y para los demás la pantalla es un arte universal que no admite fronteras de ninguna especie porque la cámara se sitúa allí donde surja un conflicto humano [...]. El grupo que defiende la tendencia del nacionalismo también se divide, a su vez, en dos ramas. Una tiende a aceptar todo lo que es del país y la otra considera que la mejor manera de exaltar lo nacional, lo autóctono, es olvidarse de la ciudad y contemplar el campo [...]. (13334)

La polémica no se establece entre lo nacional y lo universal puesto que cuanto una obra es más nacional es, a su vez, más universal. La lucha está abierta entre quienes confunden lo nacional con lo nacionalista. Entendámonos. No es lo mismo nacional que nacionalista. Lo primero es orgullo; lo segundo, una vanidad. Lo primero puede alcanzar la categoría de pecado; lo segundo de engreimiento. (Dios perdona a los pecadores pero no dice nada sobre los tontos). (135) [...] Lo mismo en México que en Buenos Aires hay quienes proponen que se circunscriba en la historia y las costumbres el fomento y firmeza de sus pantallas nacionales. Como queda dicho, eso puede conducir a un cine nacionalista por poco propenso que se sea al resbalón. (137) [...] En México y en Buenos Aires se hallan partidarios de hacer una sola clase de cinematografía: bastarse con la historia, las costumbres y el cancionero autóctonos. (144)

Frente a las polarizaciones apuntadas, Francisco Madrid esboza una respuesta matizada: "Las cinematografías nacionales deben tener su acento. Y desde luego, está naciendo esa personalidad. Pero hay que evitar los extremismos ridículos. Las escuelas estéticas terriblemente revolucionarias pasan de moda” (141). Contra la tentación nacionalista, el autor resume su opinión con la siguiente fórmula: "Poner aduanas a la cinematografía es destruirla” (145). Y otra todavía más contundente: "La pantalla tiende a la universalización y no al localismo. Es ciudad y no tribu” (139).

La posición del ensayista español plantea un camino intermedio entre los dos extemos que son el refugio en la literatura universal (a la cual recurrrieron los productores de México y Buenos Aires durante la segunda guerra mundial) y el nacionalismo folclorista, que redundaría en la marginación del aporte de los inmigrantes, como los republicanos españoles. Están en juego las opciones de producción de unos y las posibilidades de trabajo de otros. El fomento al cine argentino está entonces en discusión y se barajan

guionista de Dios se la pague, había adaptado también una novela del gaúcho Erico Veríssimo, Mirad los lirios del campo (Ernesto Arancibia, Argentina, 1947). Argentina Sono Film coprodujo asimismo Chico Viola não morreu (Román Viñoly Barreto, 1955), según fuentes brasileñas (Viany 198; Cavalcanti de Paiva 72). 
argumentos de cuño nacionalista y pedagógico para legitimar la intervención estatal: en los gobiernos militares después del golpe de 1943, así como en el peronista, el Ministerio de Educación parecía reunir al nacionalismo más cerril. Para los productores, lograr la conjunción de intereses ideológicos y comerciales dispares permitía mostrar la adecuación de la iniciativa privada a la nueva política y evitar por lo tanto el peligro de una estatalización. Dios se lo pague resuelve la contradicción creando un nuevo imaginario, que no recurre al folclore o al costumbrismo pero tampoco se aparta de la vivencia del espectador predominantemente urbano. El proceso de urbanización acelerada que conoce América Latina en general y la Argentina peronista en particular exige otras referencias: la pantalla será pues ciudad y no tribu. El populismo encuentra así un espacio simbólico a la vez desterritorializado y acorde con la iconografía o el discurso del momento. La metamorfosis operada desde el teatro varguista de Joracy Camargo al melodrama peronista de Argentina Sono Film permite reconciliar los valores conservadores y populistas, la religión y la tensión clasista, la pulsión nacionalista y la experiencia cosmopolita, la tradición y la modernidad, en una hibridación característica de la modernización conservadora que ha prevalecido en América Latina.

BIBLIOGRAFÍA

Almeida Prado, Decio de. Peças, pessoas, personagens: O teatro brasileiro de Procópio Ferreira a Cacilda Becker. São Paulo: Companhia das Letras, 1993.

Procópio Ferreira. São Paulo: Brasiliense, 1984.

Amador, María Luisa y Jorge Ayala Blanco. Cartelera Cinematográfica 1940-1949. México: UNAM, 1982.

Amadori, Luis César, dir. Dios se lo pague. Argentina Sono Film, 1948.

Ayala Blanco, Jorge. La aventura del cine mexicano. México: Era, 1968.

Barcellos, Jalusa. Procópio Ferreira, O mágico da expressão. Río de Janeiro: Funarte, 1999.

Blanco Pazos, Roberto y Raúl Clemente. Diccionario de actores del cine argentino, 19331999. Buenos Aires: Corregidor, 1999.

Borau, José Luis. Diccionario del cine español. Madrid: Alianza Editorial/Academia de las Artes y las Ciencias Cinematográficas de España/Fundación Autor, 1998.

Camargo, Joracy. Deus lhe pague. Prefacio de Procópio Ferreira. Río de Janeiro: Livraria Editora Zelio Valverde, 1945.

Cavalcanti de Paiva, Salvyano. História ilustrada dos filmes brasileiros, 1929-1988. Río de Janeiro: Francisco Alves, 1989.

Di Nubila, Domingo. Historia del cine argentino. Vol. II. Buenos Aires: Cruz de Malta, 1960.

España, Claudio. Luis César Amadori. Los directores del cine argentino n 12 . Buenos Aires: Centro Editor de América Latina/Instituto Nacional de Cinematografía, 1993. Medio siglo de cine: Argentina Sono Film. Buenos Aires: Abril/Heraldo del Cine, 1984. 
Ferreira, Procópio. Depoimentos. Vol. I. Río de Janeiro: Serviço Nacional de Teatro/ Funarte/Ministério da Educação e Cultura, 1976.

“O teatro argentino”. Procópio Ferreira apresenta Procópio. Río de Janeiro: Rocco, 2000.

Ferrer, Horacio. El libro del tango: crónica \& diccionario, 1850-1977. Buenos Aires: Galerna, 1977.

Gubern, Román. Cine español en el exilio. Barcelona: Lumen, 1976.

Kohen, Héctor R. “Estudios San Miguel”. Cine argentino, Industria y clasicismo, 1933/ 1956. Vol I. Buenos Aires: Fondo Nacional de las Artes, 2000.

Kriger, Clara. "El cine del peronismo: una reevaluación”. Archivos de la Filmoteca 31 (Valencia, febrero 1999) : 136-55.

“Dios se lo pague.” En Tierra en trance: El cine latinoamericano en 100 películas. Alberto Elena y Marina Díaz López, eds. Madrid: Alianza, 1999.

Madrid, Francisco. Cine de Hoy y de Mañana. Buenos Aires: Editorial Poseidon, 1945.

Maranghello, César. “Dios se lo pague”. Cine argentino, Industria y clasicismo, 1933/ 1956. Vol. II. Buenos Aires: Fondo Nacional de las Artes, 2000.

Othelo, Grande. Depoimentos III. Río de Janeiro: Serviço Nacional de Teatro/Funarte, 1977.

Paranaguá, Paulo Antonio. “L’Amérique Latine, des velléités aux mythes”. Stars au féminin. Gian Luca Farinelli y Jean-Loup Passek, eds. París: Centre Pompidou, 2000. 274-54. (“La star nel cinema latinoamericano. Dalle velleità ai miti.” Star al femminile. Boloña: Cineteca, 2000: 232-41).

Pina, Luís de, Org. Chianca de Garcia. Lisboa: Cinemateca Portuguesa, 1983.

Posadas, Abel. "La caída de los estudios: ¿Solo el fin de una industria?” Cine Argentino: La otra historia. Sergio Wolf, comp. Buenos Aires: Ediciones Letra Buena, 1994.

Rodríguez Monegal, Emir. Mário de Andrade/Borges: Um diálogo dos anos 20. São Paulo: Perspectiva, 1978.

Schwartz, Jorge. Vanguarda e cosmopolitismo na década de 20: Oliverio Girondo e Oswald de Andrade. São Paulo: Perspectiva, 1983.

"Down with Tordesillas”. Brazil 2000-2001: A Revisionary History of Brazilian Literature and Culture, Portuguese Literary \& Cultural Studies 4/5. University of Massachusetts: Dartmouth/UERJ, 2000. 277-93.

Viany, Alex. Introdução ao cinema brasileiro. Río de Janeiro: INL, 1959. 